\title{
DETERMINANTS OF ENTREPRENEURIAL ENGAGEMENT LEVELS IN EUROPE AND THE US
}

Isabel Grilo and Roy Thurik

ISSN 05-8

\author{
Isabel Grilo \\ Enterprise Director General \\ European Commission \\ Rue de la Loi/ Wetsrtaat 200, B-1049 \\ Brussels \\ A. Roy Thurik \\ Erasmus University Rotterdam \\ NL-3000 DR Rotterdam \\ The Netherlands
}

December 2005 


\title{
DETERMINANTS OF ENTREPRENEURIAL ENGAGEMENT LEVELS IN
} EUROPE AND THE US

\author{
by Isabel Grilo and Roy Thurik
}

This research was undertaken by the Institute for Development Strategies. The statements, findings, conclusions, and recommendations are those of the authors and do not necessarily reflect the views of the Institute for Development Strategies, or the Ameritech Foundation. 


\title{
Isabel Grilo ${ }^{\mathrm{b}}$ and Roy Thurik
}

\author{
${ }^{a}$ Centre for Advanced Small Business Economics, Rotterdam School of Economics, Erasmus University Rotterdam, \\ P.O. Box 1738, 3000 DR Rotterdam, the Netherlands, Tel.: +31-10-4081398, EIM Business and Policy Research, P.O. \\ Box 7001, 2701 AA Zoetermeer, the Netherlands and Max Planck Institute of Economics, Jena, Germany. \\ thurik@few.eur.nl \\ b DG Enterprise, European Commission, B-1049, Brussels, Belgium, Tel.: +32-2-2951502, GREMARS, Université de \\ Lille 3 and CORE, Université Catholique de Louvain. \\ isabel.grilo@cec.eu.int
}

\begin{abstract}
Determinants from different streams of literature and spanning different disciplines are used to explain entrepreneurial decisions. A multinomial logit model and survey data from the old $15 \mathrm{EU}$ member states, Norway, Iceland, Liechtenstein and the US are used to establish the effect of demographic and other variables on various entrepreneurial engagement levels. These engagement levels range from "never thought about starting a business" to "thinking about it", "taking steps for starting up", "having a young business", "having an older business" and "no longer being an entrepreneur". Data of two Entrepreneurship Flash Eurobarometer surveys (2002 and 2003) containing over 20,000 observations are used. Other than demographic variables, the set of explanatory variables used includes the perception by respondents of administrative complexities, of availability of financial support and of risk tolerance, the respondents' preference for self-employment and country specific effects. The most striking result is that the perception of lack of financial support has no discriminative effect across the various levels of entrepreneurial engagement.
\end{abstract}

Version: June 2005

Prepared for: Nascent Entrepreneurship: the Hidden Potential, Durham Business School, September 2123, 2005

Document: Grilo thurik for sbej special issue v10 mpi 2/21/2006 3:49:00 PM

JEL-code: M13, H10, J23, R12

Keywords: entrepreneurship, determinants, nascent entrepreneurship, multinomial logit, barriers to entry, Europe

Acknowledgement: The authors would like to thank David Audretsch, Reena Bhola, Rob van der Horst, Jesús Maria Irigoyen, Mirjam van Praag, André van Stel, Lorraine Uhlaner, Ingrid Verheul, Marco Vivarelli, Sander Wennekers and the participants of the conference Entrepreneurship and local development: comparing Italian and foreign experiences (Milan, Chamber of Commerce, April 26, 2004), The Summer Institute (Jena, Max Planck Institute of Economics, June 21-24, 2004) and the Empirical research in entrepreneurship conference: bridging theory and practice (Los Angeles, UCLA Anderson School of Management, June 22-24, 2005) for their comments on earlier versions. An early version of the present paper was on the program of the RENT XVIII Conference (Copenhagen, November 26, 2004). The present paper is a thoroughly revised version of paper \#30-2004 (papers of entrepreneurship, growth and economic policy) of the Max Planck Institute of Economics, Jena, Germany. The views expressed here are those of the authors and should not be attributed to the European Commission.

Corresponding author: Roy Thurik, Rotterdam School of Economics, Erasmus University Rotterdam, P.O. Box 1738, 3000 DR Rotterdam, the Netherlands, thurik@few.eur.nl 


\section{Introduction}

When defining or measuring entrepreneurship, a broad array of definitions and measures has been proposed (Hébert and Link, 1989; Bull and Willard, 1993; Lumpkin and Dess, 1996; OECD, 1998; Van Praag, 1999). Similarly, the determinants of entrepreneurship span a wide range of theories and explanations (Brock and Evans, 1989; Gavron, Cowling, Holtham and Westall, 1998; OECD, 1998; Blanchflower, 2000 and 2004; Uhlaner, Wennekers and Thurik, 2002; Arenius and Minniti, 2005). Moreover, the impact of entrepreneurship on economic development is receiving growing attention (Baumol, 1990; Wennekers and Thurik, 1999; Carree and Thurik, 2003 and 2006; Acs, Audretsch, Braunerhjelm and Carlsson, 2005). Despite the lack of consensus with respect to different aspects of entrepreneurship, scholars appear to agree that the level of entrepreneurial activity varies systematically both across countries and over time (Rees and Shah, 1986; De Wit and Van Winden, 1989; Blanchflower and Meyer, 1994; Blanchflower, 2000 and 2004). ${ }^{1}$ This variety plays an important role in the present paper.

It has long been known that the level of entrepreneurship, expressed as the percentage of owner/managers of incorporated and unincorporated businesses relative to the labor force, differs strongly across countries. This variance is related to differences in levels of economic development. In particular, evidence has been assembled for an underlying U-shaped relationship between the level of business ownership (self-employment) and per capita income. There is general consensus about the 1980s being the turning point when entrepreneurship rates reversed their long-term downward trend. ${ }^{2}$ While it is clear that such a shift has taken place, it is less clear why it has taken place. The ICT revolution together with the move towards globalized markets is often mentioned (Audretsch and Thurik, 2000, 2001 and 2004). Also, large firms have been subjected to waves of downsizing and restructuring and entrepreneurship has been (re)-discovered as an organizational tool in large companies and clusters of smaller ones (Uhlaner, Wennekers and Thurik, 2002). ${ }^{3}$ Also, this variance is related to diverging demographic, cultural and institutional characteristics (Blanchflower, 2000; Verheul, Wennekers, Audretsch and Thurik, 2002). ${ }^{4}$ Time serial effects will play no role in the present papers since data are collected in 2002 and 2003.

Also the dynamics of entrepreneurship, expressed as the rate of nascent entrepreneurship or the prevalence of young enterprises, show a wide-ranging diversity across nations. Research in the framework of the Global Entrepreneurship Monitor (GEM) shows that there are substantial differences in the dynamics of entrepreneurship across countries with the developed Asian and Central European countries ranking lowest, followed by Europe. Substantially higher levels are found in the former British Empire Anglo countries (including US) and still higher rank Latin America and developing Asian countries (Reynolds, Bygrave, Autio, Cox and Hay, 2002; Acs, Arenius, Hay

\footnotetext{
${ }^{1}$ See Van Stel (2005) for a description of the COMPENDIA data set covering business ownership rates across 23 OECD countries in the 1972-2002 period. See also the various executive reports of the Global Entrepreneurship Monitor, e.g., Acs, Arenius, Hay and Minniti (2005) for data on nascent and young firms. Finally, see the various editions of the Flash Eurobarometer (http://europa.eu.int/comm/enterprise/enterprise_policy/survey/eurobarometer_intro.htm).

2 The downward trend is documented in Kuznets (1966) and the turning point in Blau (1987), Acs, Audretsch and Evans (1994) and Acs, Carlsson and Karlsson (1999). Carree, Van Stel, Thurik and Wennekers (2002) and Audretsch, Carree, van Stel and Thurik (2002) test for this U-shape using business ownership data and Wennekers, van Stel, Thurik and Reynolds (2005) using data of nascent entrepreneurs.

${ }^{3}$ Thurik (1996 and 1999) deals with some mechanisms of the change from large to small firms.

${ }^{4}$ In a recent series of studies some cultural drivers of entrepreneurship have been investigated: post-materialism in Uhlaner and Thurik (2004), dissatisfaction in Noorderhaven, Wennekers, Thurik and van Stel (2004) and uncertainty avoidance in Wennekers, Thurik, van Stel and Noorderhaven (2003).
} 
and Minniti, 2005). Also regarding the dynamics of entrepreneurship the relation with the levels of economic development is established. ${ }^{5}$

The present study aims at giving some indicators of differences for both the level and the $d y$ namics without giving an explanatory framework at the country level. An explanation of these differences, however, is much needed as many governments attach high hopes to a positive effect of entrepreneurship on economic well-being and accordingly try to promote new business start-ups.

Comparing the level of entrepreneurship across nations is difficult. Moreover, setting up a business is a process (Reynolds and White, 1997; Reynolds, 1997) where a discrimination can be made between stages such as conception, gestation, infancy, adolescence, maturity and decline. Often conception, gestation and infancy stages are referred to as the dynamics of entrepreneurship while the adolescence, maturity and decline stages as the level of entrepreneurship. In the present study we will distinguish between seven stages of entrepreneurship for which systematic data are available at the level of individuals for 19 countries. These stages are called engagement levels. The stages include two nascent ones ("thinking about it" and "taking steps for starting up") ${ }^{6}$, two business ones ("having a young business" and "having an older business"), two exit ones ("gave up" and "no longer being an entrepreneur") and an outsider one ("never thought about it"). Next to these seven stages we will also include the preference for entrepreneurship over paid employment. This is sometimes referred to as latent entrepreneurship. ${ }^{7}$

In the present paper we address the issue of the determinants of the various engagement levels, making use of an Eclectic Framework of entrepreneurship first introduced in Audretsch, Thurik, Verheul and Wennekers (2002). The purpose of this framework is to understand and analyze what determines entrepreneurship. The Eclectic Framework of entrepreneurship attempts to integrate the different strands of the literature into a unifying framework. At the heart of the framework is the integration of factors shaping the demand for entrepreneurship on the one hand, with those influencing the supply of entrepreneurs on the other. The Eclectic Framework also creates insight into the role of government policy by identifying the channels through which policy instruments shift either the demand or the supply sides.

In the empirical part of this paper we present a multinomial logit model which estimates the influence of a set of explanatory variables on various entrepreneurial engagement levels using survey data (2002 and 2003) from the 15 old EU member states, Norway, Iceland, Liechtenstein and the US. These engagement levels range from "never thought about starting a business" to "thinking about it”, "taking steps for starting up", "having a young business", "having an older business" and "no longer being an entrepreneur". Other than demographic variables such as gender, age and education level, the set of explanatory variables includes the perception ${ }^{8}$ by respondents of administrative complexities, of availability of financial support, a rough measure of risk tolerance, the respondents' preference to be self-employed and country specific effects. The country specific effects are used as a control mechanism and will not be further explained.

Data from the Entrepreneurship Flash Eurobarometer surveys containing over 20,000 observations are used. The data collection differs from that of the Global Entrepreneurship Monitor in that a lower number of interviews are held per country in favor of a higher level of survey homogeneity across countries. ${ }^{9}$ Also, it is limited to highly developed countries such as EU member states and the US. This eliminates the complexities of comparing totally different demographics and attitudes of highly developed and developing countries. The Entrepreneurship Flash Euro-

\footnotetext{
${ }^{5}$ See Van Stel, Carree and Thurik (2005) and Van Stel, Wennekers, Thurik and Reynolds (2005).

${ }^{6}$ See Reynolds, Bosma et al. (2005) for the narrower definition of nascent entrepreneurship used in the Global Entrepreneurship Monitor.

${ }^{7}$ Blanchflower, Oswald and Stutzer (2001), Grilo and Irigoyen (2005) and Grilo and Thurik (2005a and 2005b).

${ }^{8}$ The important role of perception variables is shown in Arenius and Minniti (2005).

${ }^{9}$ See Reynolds, Bosma et al. (2005) for details of the data collection design and implementation of the Global Entrepreneurship Monitor.
} 
barometer surveys are conducted on behalf of the European Commission's Enterprise DirectorateGeneral, and the key findings are presented in the Eurobarometer surveys of European Commission (Flash Eurobarometer 123 for 2002 and Flash Eurobarometer 146 for 2003). ${ }^{10}$

The contribution of the present paper is twofold. First, to our knowledge it is the first to discriminate between more than two engagement levels of entrepreneurship. Standard binary choice models discriminate between nascent entrepreneurship and no engagement or entrepreneurship and no engagement (Blanchflower, Oswald and Stutzer, 2001; Blanchflower and Oswald, 1998; Grilo and Irigoyen, 2005; Grilo and Thurik, 2005a and 2005b) of success and failure (i.e. survival) in the nascent phase (Vivarelli, 2004; Van Gelderen, Thurik and Bosma, 2005). The present study discriminates between seven entrepreneurial engagement levels. We use a multinomial choice model which predicts the probability that an individual chooses one of the engagement levels. Similar setups can be found in Earle and Sakova (2000) where two types of self-employment and wage employment are predicted and Cooper, Gimeno-Gascon and Woo (1994) where entrepreneurial failure, survival and growth are predicted. Secondly, we incorporate a multi-level effect using country dummies as covariates. In this fashion we can control for country effects when using individual socio-demographic and perception influences. ${ }^{11}$

The paper is organized as follows: in section two the literature of the determinants of entrepreneurship is dealt with in five parts (introduction, economic theory, empirical evidence, framework approach and our setup). Section three provides a report of our empirical analysis of the determinants of engagement levels (observations and variables and estimation results). Section four concludes.

\section{Determinants of entrepreneurship}

\subsection{Introduction}

Entrepreneurship is a multidimensional phenomenon spanning different units of observation ranging from the individual to the firm, region or industry and even nation (Wennekers and Thurik, 1999; Davidsson, 2004). Due to this multidimensional nature the conceptual and theoretical approaches have built on a variety of disciplines such as economics, sociology and psychology (Uhlaner, Wennekers and Thurik, 2002). In the $20^{\text {th }}$ century three scholars, Schumpeter, Kirzner and Knight, stand out in having shaped the subsequent literature on entrepreneurship through their vision of the phenomenon. ${ }^{12}$

The Schumpeterian tradition, breaking with the orthodox approach which tended to analyze market functioning and agents' decisions as an equilibrium phenomenon, stresses the inherent disequilibrium nature of market dynamics. In this school of thought entrepreneurship is almost impossible to disassociate from innovative performance. It is the driving force behind firm creation and market dynamics and is indeed seen as the consequence of entrepreneurial innovation. The entrepreneur is the 'persona causa' of pushing the economy out of equilibrium.

In the Kirznerian world entrepreneurs display manifest alertness to exploit previously unchartered (profit) opportunities. They are involved in a process of learning and discovery with the result that the economy is pushed back towards equilibrium. Kirznerian entrepreneurs operate in a different phase of the product life cycle than do Schumpeterian ones.

\footnotetext{
${ }^{10}$ See http://europa.eu.int/comm/enterprise/enterprise_policy/survey/eurobarometer_intro.htm.

11 This multi-level approach is also applied in Blanchflower, Oswald and Stutzer (2001) with some socio-demographic variables and in Grilo and Irigoyen (2005) where perception variables are used.

${ }^{12}$ Hébert and Link (1989) show that these three intellectual traditions can be traced to Cantillon's Essai sur la Nature du Commerce en Général (translated by H. Higgs, 1931, London: McMillan). Casson (1982) and Wennekers and Thurik (1999) attempt to make a synthesis again.
} 
Knight's views have also strongly contributed to the subsequent literature on entrepreneurship by stressing the importance of two functions of entrepreneurs: providers of entrepreneurial inputs who receive a return for bearing (non-calculable) risk.

\subsection{Economic theory and the level of the individual}

At the individual level and from an economic theory perspective, the tools of neo-classical microeconomics have provided a framework for studying self-employment decisions known as the theory of income choice. This field has proved useful in describing some of the factors influencing this occupational decision.

This approach views agents as (expected)-utility maximizers taking an occupational choice decision - to become employees or entrepreneurs (self-employed) - on the grounds of the utility associated with the returns accruing from the two types of activity. Though the specification and the working assumptions used in this strand of literature vary according to the factor being emphasized as playing the key role in explaining self-employment decisions, most of this constrained optimization approach can be traced back to the vision of the role of an entrepreneur found in the work of Knight (1921).

Knight views the entrepreneur as playing a twofold function: “(a) exercising responsible control and (b) securing the owners of productive services against uncertainty and fluctuations in their incomes” (Knight, 1921, p. 2), in other words, as provider of entrepreneurial inputs and as risk bearer. The first 'provider' function plays a role answering the question why different individuals make different occupational choices by emphasizing the role of entrepreneurial ability in the decision to become an entrepreneur. Several authors follow this route by postulating differences across potential entrepreneurs (or firms) in terms of some form of entrepreneurial efficiency (Jovanovic, 1982 and 1994; Lucas, 1978; Murphy, Shleifer and Vishny, 1991; Holmes and Schmitz, 1990 and Lazear, 2004).

The second 'risk bearer' function gives a particular role to the presence of risk and underlines the importance of risk attitudes in the occupational choice. In Kihlstrom and Laffont (1979) and Parker (1996 and 1997) the degree of risk aversion and the differences in risk of the two occupational alternatives determine the occupational choice. Another aspect that has been emphasized in explaining different occupational choices is the existence of liquidity constraints. Evans and Jovanovic (1989) building upon Lucas (1978) and Jovanovic (1982) show that under certain conditions, due to capital constraints, there is a positive relationship between the probability of becoming self-employed and the assets of the entrepreneur. ${ }^{13}$ This influential study led to many follow up investigations of both conceptual ${ }^{14}$ and empirical nature ${ }^{15}$.

\subsection{Empirical literature and the level of the individual}

Some empirical literature has built on the insights from the occupational choice models and has sought to test the role of factors influencing self-employment decisions. These studies attempt

\footnotetext{
${ }^{13}$ Next to the 'provider' and 'risk-bearing' role of the entrepreneur Knight also refers to wealth as a condition for entrepreneurial action. The research started by Evans and Jovanovic (1989) can be seen as an exploration of this third condition.

${ }^{14} \mathrm{Xu}$ (1998) discusses a possible downward bias in wealth data. Cressy (1999) and Harada and Kijima (2005) challenge the necessity of the liquidity constraint condition. Cressy (2000) introduces business uncertainty and decreasing risk aversion.

15 The empirical establishment of whether wealthier individuals have a higher probability of becoming entrepreneur is widely investigated. See Holtz-Eakin, Joulfaian and Rosen (1994) and Taylor (2001). Hurst and Lusardi (2004) show that the relationship between household wealth and the propensity to start a business is highly non-linear: using American income data they show that a positive relation can be found only for households in the top 5\% of the wealth distribution. An interesting extension of the literature can be found in Burke, FitzRoy and Nolan (2000) which uses a new model and a large single cohort British data set to provide estimates of both the self-employment decision as well as income and job creation. Their model distinguishes between the impact of liquidity constraints on the probability to start a firm and subsequent performance. Their setup leads to conclusions such as that university education leads to a lower propensity to start a firm but improves both performance measures.
} 
to explain the probability of being or becoming self-employed (see Parker, 2004 for references). The earnings differential between self-employment and salaried employment plays a key role in these occupational choice models (Rees and Shah, 1986; de Wit and van Winden, 1989). Moreover, a variety of variables is used to describe the factors influencing returns to self-employment and to salaried employment, their relative risk, or the preferences and abilities of the individuals. Most studies in this area use longitudinal data for a given country and have as dependent variable the transition into self-employment and sometimes the business longevity and the exit from selfemployment. Typical explanatory variables include age, gender, race, education, earnings, capital assets, previous professional experience, marital status, professional status of the parents, and scores from psychological tests ${ }^{16}$. The empirical results obtained from this approach are summarized below. In this summary we anticipate the use of the Flash Eurobarometer Surveys 2002 and 2003 and their data limitations.

Being (or becoming) self-employed received ample attention as a variable to be explained. Major influencing factors are listed below.

- Most studies find that men have a higher probability of engaging in entrepreneurship than women. ${ }^{17}$

- The likelihood of becoming self-employed varies with age. Many business owners are within the age category of 25 to 45 years old. ${ }^{18}$ Nascent entrepreneurship rates are highest in the age category of 25 to 34 years old, although some studies suggest that people increasingly start businesses at a younger age. ${ }^{19}$

- The level of education is a variable for which contrasting results have been obtained. The results vary regarding the existence of a significant impact and the nature of this impact. Among the studies finding that education has a significant impact, the nature of the impact varies from study to study - some find a positive relation others a negative one and still others a negative up to some level of education and positive thereafter. $^{20}$

- Financial constraints, often evaluated through the role of capital assets in the probability of being self-employed ${ }^{21}$, are generally found to have a negative impact on the decision to become an entrepreneur.

- Risk tolerance - as could be expected - is found to increase the probability of being self-employed. $^{22}$

${ }^{16}$ Examples of empirical work following this approach can be found in Bates (1990), Blanchflower (2004), Blanchflower and Meyer (1994), Blanchflower and Oswald (1998), Blau (1987), Douglas and Shepherd (2002), Evans and Leighton (1989, 1990), Grilo and Irigoyen (2005), Grilo and Thurik (2004), Lin, Picot and Compton (2000), Rees and Shah (1986), Reynolds (1997), Wagner (2003) and de Wit and van Winden (1989).

17 There are many sources. See Minniti, Arenius and Langowitz (2005) and Grilo and Irigoyen (2005). According to Reynolds, Bygrave, Autio, Cox and Hay (2002) men are about twice as likely involved in entrepreneurial activity than women.

${ }^{18}$ See Storey (1994), Reynolds, Hay and Camp (1999) and Grilo and Thurik (2005a).

${ }^{19}$ See Delmar and Davidsson (2000).

${ }^{20}$ Robinson and Sexton (1994) and Cooper and Dunkelberg (1987) show that the self-employment decision is influenced by educational attainment. However, a study at the macro level by Uhlaner and Thurik (2004) shows that a higher level of education in a country is accompanied by a lower self-employment rate. See also de Wit and van Winden (1989). Blanchflower (2004) reports that education is positively correlated with self-employment in the US but negatively so in Europe. Using Eurobarometer data Grilo and Irigoyen (2005) report a U-shaped relationship for 2000 while Grilo and Thurik (2005a) show that this relation is negative up to the intermediate education level and non-existent for higher levels. The results of Delmar and Davidsson (2000) and Davidsson and Honig (2003) show a clear education effect for nascent entrepreneurs.

${ }^{21}$ The argument behind the use and interpretation of capital assets to proxy financial constraints is the so-called equivalence theorem in Evans and Jovanovic (1989). See Cressy (1999) for a discussion of the limitations of this theorem.

${ }^{22}$ See Grilo and Irigoyen (2005) and Grilo and Thurik (2005a) using 2000 and 2004 data respectively. 
- Grilo and Irigoyen (2005) and Grilo and Thurik (2005a) have studied the role of perceptions of administrative complexities and financial constraints on (latent) entrepreneurship. The results indicate that perceived administrative complexities have a negative impact while perceived financial constraints do not seem to play a role.

- In cross country comparisons, and for the role of country specific effects, the few studies addressing this issue indicate that entrepreneurship is stronger in the US than in European countries. ${ }^{23}$

There are many other determinants of being or becoming self-employed which are dealt with in the literature but not in the present study such as employment status (wage, part-time, unemployment, characteristics of the workplace), financial situation (including more than the constraints mentioned above, such as, household income, assets, home ownership, wealth, windfall effects, number of persons in the household), experience (current work, professional background, former entrepreneurship), minority behavior, immigrant behavior, family firm effects, attitudinal effects (past failures, relatives with experience, confidence, knowing other entrepreneurs, opportunity perception), etc. See Blanchflower (2004), Wagner (2004) and Arenius and Minniti (2005) for surveys.

\subsection{Beyond economics: the framework approach}

These economic approaches though having the advantages inherent to any rigorous modeling of a situation - that is, establishing a clear link between the assumptions and the results - will also, almost by definition, fail to encompass all the possibly relevant aspects that determine an individual's decision. In this respect, contributions from fields such as sociology and psychology have stressed the importance of factors such as the society's attitudes towards entrepreneurs and whether failure is strongly stigmatized in a society; the strength of interpersonal links in some communities; specific psychological characteristics of individuals that make them more prone to take risks and seek success (the so-called internal locus of control) and so forth.

In analyzing determinants of entrepreneurship, Verheul, Wennekers, Audretsch and Thurik (2002) present an Eclectic Framework of the determinants of entrepreneurship bringing together elements from different fields and levels of analysis, some of which have already been discussed above. $^{24}$

The multidimensionality of entrepreneurship is reflected both in the way it is defined and in the way it is measured. ${ }^{25}$ Briefly, concerning the determinants of entrepreneurship, the theory distinguishes various disciplines, several levels of analysis (micro, meso and macro), and classifies the explanatory factors into two categories - supply and demand side. From the demand side the framework focuses on factors that influence the industrial structure and the diversity of consumers' tastes, such as technological development, globalization and standard of living developments. The supply side looks into the structure of the population and the way this affects the likelihood of

${ }^{23}$ Acs, Arenius, Hay and Minniti (2005) and Grilo and Thurik (2005a). In Grilo and Thurik (2005b) it is shown that the ten new EU member states do not significantly differ in their entrepreneurship behavior when compared to the fifteen old ones.

${ }^{24}$ See Wennekers, Uhlaner and Thurik (2002) for an extension the framework including two historical case studies: the Dutch Golden Age of the 17th century and Britain's First Industrial Revolution (1760-1830). See Grilo and Thurik (2004) for a concise version of the framework including an empirical application. Alternative frameworks are provided by Busenitz, Gomez and Spencer (2000), Stevenson and Lundström (2001) and by the Global Entrepreneurship Monitor (Reynolds, Hay and Camp, 1999 and Reynolds, Bygrave, Autio, Cox, and Hay, 2002). The Global Entrepreneurship Monitor approach is updated in Acs, Arenius, Hay and Minniti (2005).

${ }^{25}$ Verheul, Wennekers, Audretsch and Thurik (2002) refer to definitions of entrepreneurship from economics (based on both the functions of the entrepreneur and the perception of economic opportunities and innovation) and to those from the managerial world, where entrepreneurship is referred to as a way of managing. As regards measurement, two approaches are suggested. Business ownership and self-employment are considered as equivalent to entrepreneurship and can be the basis for constructing static indicators. From a dynamic perspective, the proposed measures of entrepreneurship are based on nascent and start-up activity. See also Wennekers, Uhlaner and Thurik (2002). 
becoming entrepreneur. Population growth, urbanization rate, age structure, participation of women in the labor market, income levels and unemployment are example of such factors. While the supply and demand sides refer to the macro level, the framework also integrates the decisionmaking process explaining how and why individuals make the choice to become self-employed as opposed to other job opportunities in terms of risks and rewards of different occupational alternatives - along the lines discussed above.

Reference must also be made to the distinction between actual (E) and 'natural' rates of entrepreneurship (E*). ${ }^{26}$ The concept of 'natural' rate is relevant for analyzing government opportunities for and modalities of intervention. Clearly, there is room for the government to act when the actual rate of entrepreneurship deviates from the 'natural' rate. Several types of measures can be distinguished:

G1 Intervention on the demand side of entrepreneurship. Examples of this type of intervention are policies stimulating technological developments, competition policy and establishment legislation. By fostering technological development, and improving accessibility of markets, governments create opportunities for entrepreneurial ventures and the creation of enterprises.

G2 Intervention on the supply side. These aim at influencing the characteristics or number of people in the population: immigration policy and fiscal treatment of families with children.

G3 Influencing the availability of resources, skills and knowledge of potential entrepreneurs. These are input-related policies that aim at increasing the availability of inputs (e. g. financial and knowledge) into the entrepreneurial process.

G4 Influencing preferences. Although the preferences of individuals, reflected in values and attitudes, are strongly determined by culture, governments can play a role through the education system in order to influence people's values and attitudes.

G5 Influencing the risk-reward profile of entrepreneurship. Policies in the field of taxation, social security, market regulation and bankruptcy can influence the decisionmaking process of individuals.

As is clear from this setup, other than personal characteristics, the overall environment in which business is conducted plays a crucial role in fostering or weakening entrepreneurial activities both in terms of firm creation, of firm expansion and of implementation of process, product and management innovation within a firm. From a policy point of view these "framework conditions" are the aspects that offer wider scope for action. Issues such as the fiscal environment, labor market regulations, administrative complexities, intellectual property rights, bankruptcy law, education and skill upgrading, etc. are understandably crucial in determining the entrepreneurial dynamism of an economy.

\subsection{Our setup}

Figure 1 gives a graphical representation of the Eclectic Framework including the variables we will use in the present study to explain the various engagement levels of entrepreneurship. The five ways of government intervention are denoted by G1 through G5. The discrepancy between actual (E) and 'natural' rates of entrepreneurship ( $\left.E^{*}\right)$ leads to (lack of) opportunities for entrepreneurial action and can also be an input for government intervention. The risk reward profile of entrepreneurs is driven by opportunities on the one hand and their willingness ${ }^{27}$, i.e., (lack of) necessity on the other. Resources, abilities/traits and preferences are the components of the willingness to start a business or to remain in business.

\section{Figure 1: Eclectic Framework and the variables used in the present study}

\footnotetext{
${ }^{26}$ See Carree, van Stel, Thurik and Wennekers (2002) and Audretsch, Carree, van Stel and Thurik (2002).

${ }^{27}$ Praag and Ophem (1995).
} 


\section{Determinants of engagement levels in European and American en- trepreneurship}

\subsection{Observations and variables}

This section estimates a multinomial Logit model where the dependent variable is a categorical variable describing different "levels" of engagement in the entrepreneurial process. Data are from two Entrepreneurship Flash Eurobarometer surveys conducted in the fall of 2002 and 2003 and covering the 15 EU member states, Norway, Iceland, Liechtenstein and the US. Together, these surveys contain over 20,000 observations of which 17631 can be used for our estimation.

The following question was used for the dependent variable: "Have you started a business recently or are you taking steps to start one?" The following options for answering were given:

- "It never came to your mind"

- "No, you thought of it or had already taken steps to start a business but gave up"

- "No, but you are thinking about it"

- "Yes, you are currently taking steps to start a new business"

- "Yes, you have started or taken over a business in the last 3 years and still active"

- "Yes, you started or took over a business more than 3 years ago and still active"

- "No, you once started a business, but currently you are no longer an entrepreneur"

Each one of these possible answers reflects a different, and increasing, level of involvement in entrepreneurship. Note that the last four options translate an active role in the entrepreneurial world, while the first three have a softer component of varying degrees of interest in the entrepreneurial activities. Respondents belonging to the last group may either have been successful entrepreneurs who retired or transferred their business or entrepreneurs which met with less success and failed. The country averages per engagement level are given in Table 1. Clear differences between European countries and the US can be observed. In the US only 3\% gave up whereas the European unweighted average is $10 \%$. The "thinking”, "taking steps" and "young business" categories in Europe are considerably lower than in the US (unweighted averages of 13, 3 and 3\% versus 23, 8 and $7 \%$ in the US).

\section{Table 1: Percentages per engagement level per country}

Insert Table 1 about here

The explanatory variables used here can be divided into three types.

Socio-demographic variables: gender, age and level of education. "Age when finished full education" is used to construct three education levels: The first encompasses all those with no education or having left school before the age of 15; the second those who left school between the age of 15 and 21; and the third those having left school past the age of $21 .^{28}$ A dummy variable is used for the lower level and another for the higher level so that the intermediary level works as the base.

\footnotetext{
${ }^{28}$ We chose not to treat this information as a continuous variable due to the discontinuity associated with the group "never having attended full time school".
} 
Perception and preference variables: these include perception of lack of financial support, perception of administrative complexities, preference for self-employment and risk tolerance.

The perception of lack of available financial support, the perception of complexity of administrative procedures and risk tolerance are captured, respectively, by the following questions: "Do you strongly agree, agree, disagree or strongly disagree with the following statements?” Categories then are

- "It is difficult to start one’s own business due to a lack of available financial support”.

- "It is difficult to start one's own business due to the complex administrative procedures"

- "One should not start a business if there is a risk it might fail"

For each statement a dummy variable was constructed. The dummy variables take the value " 1 " in the case of "strongly agree" or "agree" for the first two statements. These first two variables capture, at best, the perception individuals have of the existence of financial or administrative barriers not their actual existence. Most likely these perceptions are the closer to reality the higher the involvement of the respondent in active entrepreneurial activities.

For the third statement the risk tolerance dummy takes value " 1 " if "disagree" or "strongly disagree". Clearly, this is a very rough indicator of risk attitudes and calling this dummy "risk tolerance" may be abusive; nevertheless, in the absence of a better measure we believe it gives some useful information on how taking risks is perceived by the respondent.

Preference for self-employment is constructed on the basis of a direct question asking respondents whether they would prefer to be employed or self-employed.

Country dummies: country-specific effects are evaluated using country dummy variables with the US as the base. Therefore the coefficients associated with these variables are to be interpreted as the impact of being in the corresponding country rather than being in the US.

\subsection{Estimation results}

The factors presented in Table 1 describe the effect of the corresponding variable on the odds (ratio of two probabilities) of the category in question relative to the base category (in our case the base is "It never came to your mind"). A factor above unity implies that the corresponding explanatory variable increases the odds of belonging to the category in question relative to the group "It never came to your mind". Conversely, a factor below unity implies that the variable decrease the odds.

Table 2: Odds relative to “never having considered starting a business": effect of one unit change in independent variables

Insert Table 2 about here

Below we summarize the main results of Table 2. We will concentrate on the effect of three variables: gender, financial obstacles and administrative complexity. We will also discuss country effects.

\section{Gender}

Relative to not thinking about setting up a business, the odds of any other option are higher for men than for women. This is particularly the case when considering the odds of having an active business where, relative to not considering starting one, the odds for men are almost twice those of women for businesses with less than three years and two and a half as high for businesses with more than three years. Remark that these results are obtained from a regression where preferences for self-employment have been accounted for. It therefore suggests that this gender differen- 
tial goes beyond the often observed lower entrepreneurship preferences of women. This suggests two fronts for action if women are to become equally represented in the entrepreneurial world. Firstly, to act at the level of preferences by investigating and addressing the factors responsible for this possible lack of entrepreneurial drive. And secondly, to address more directly the obstacles faced by women that may be hindering the materialization of entrepreneurial spirit into actual entrepreneurship.

\section{Administrative complexities}

Relative to never having considered setting up a business, the odds of having thought and given up are not significantly affected by the perception of administrative complexities. However, the odds of other more active entrepreneurial positions such as actually having started one (whether active for less or longer than three years) or having once been an entrepreneur are significantly negatively affected by a perception of administrative complexity. The results suggest that for those who gave up on the idea of starting a new business the recognition of such obstacle is not binding enough to "make" them statistically different from those never having considered an independent status. What is however revealing in these results is the fact that when it comes to a more "engaged" entrepreneurial position these obstacles do play a role and one that hinders entrepreneurship.

\section{Lack of financial support}

Regarding the influence of lack of financial support the important result is the lack of significance of this variable across the board. In plain words this result means that the fact of acknowledging a lack of financial support plays no role in one's entrepreneurial position. Unlike with administrative obstacles, lack of financial support does not seem to discourage an active involvement in entrepreneurial activity; even for those categories reflecting an effective business activity their odds relative to not considering an entrepreneurial activity are not significantly affected by a perception of financial obstacles. The result concerning financial obstacles is in stark contrast with the result for administrative complexities where the expected negative effect is evident for engaged entrepreneurship. Clearly, this somehow surprising result begs further investigation. In interpreting these results we have to bear in mind that the odds under consideration here are those of each category relative to a lack of interest for entrepreneurship. The obvious question is then whether a lack of financial support may play a role in the odds of other pairs of categories. Could it be the case that this obstacle is important in determining the odds of actually having a business relative to thinking about starting one or relative to having given up? Or, could it play a role in the odds of having an older business relative to having a younger one? Tests along these lines show that this variable has no significant effect on the odds of any pair of categories.

\section{Country dummies}

The large amount of individual country dummies for every category prevents an exhaustive discussion. However, the most relevant results are that

- Strikingly, the odds of having considered and subsequently having given up starting a business relative to not having thought about it are much stronger for any European country in the sample than for the US. Giving up rather than even considering an entrepreneurial activity appears to be a characteristic more present in the European population.

- When it comes to thinking about setting up a business as opposed to not considering it at all, the result is almost the opposite of the preceding: with the exception of Denmark and Austria, no European country has higher odds than the US. Most countries have significantly lower odds and a few, such as Germany, Greece, Ireland, and the UK, are at par with the US.

- Looking at a more engaged stage in the entrepreneurial process, currently taking steps to start a new business, relative again to showing no interest, the results are the 
following: with the exception of Denmark, and Ireland for which the odds are not statistically different than in the US, all other European countries fare less well than the US.

- Relative to not considering an entrepreneurial activity, the odds of having a "young" business (less than three years) are never higher for European countries than for the US (for some countries they are statistically lower and for others they are at par).

- The situation changes dramatically when we look at the odds of having an older business (always relative to not wanting to start one). Here no country scores below the US and with the exception of Belgium, Spain, France and Portugal for which the situation is not statistically different from the US, all other European countries have significant higher odds than the US.

- Finally, it remains to see how nationality influences the odds of having once started a business but not being any longer an entrepreneur, relative to not being interested in such activities. Here no European country has lower odds than the US (some are at par while others are clearly above). This class of "have been entrepreneurs" is of course a heterogeneous group which makes it difficult to comment on these results. Its message would have to be tempered by the information on why the respondent is no longer an entrepreneur: has he succeeded in his venture and transferred it or has the business been a failure? Unfortunately we do not possess this type of information.

In the presentation of the results chosen here we looked systematically at the odds of belonging to a given class relative to the class "It never came to your mind". Another way of looking at these results would be to look at odds of other pairs of classes. One might for instance want to know what the impact is of a certain explanatory variable on the odds of having an older business relative to having a younger one. The value of these impacts (though not its statistical significance) can be easily obtained from Table $2 .^{29}$ Below three instances of these impacts are given.

The odds of having a business (whether for more or less than 3 years) relative to having given up setting a business are negatively influenced by the perception of administrative complexities but not by lack of financial support. In the same spirit, the odds of having a business relative to thinking about it also decrease in the presence of administrative perceived complexities but are not affected by lack of financial support. ${ }^{30}$ The odds of having a longer established business (more than 3 years) relative to having a younger business (less than 3 years) are very significantly increased by belonging to any of the European countries in the sample rather than being American. Being a man also increases these odds. ${ }^{31}$

\section{Conclusion}

Entrepreneurship is a multidimensional concept: its definition depends largely on the focus of the research undertaken. Hence, measurement and comparison of the level of entrepreneurship for different time periods and countries suffers from the absence of a universally agreed upon set of indicators (OECD, 1998). One could say that the cross-country comparison of entrepreneurship and its potential determinants is still in its infancy. In the present study we use a data set uniform across countries and measuring seven entrepreneurial engagement levels.

In the last two decades entrepreneurship re-emerged as a key agenda item of economic policy makers across Europe, both for individual nations as well as for the European Union as a whole (OECD, 1998; European Commission, 1999 and 2004; EZ, 1999). It also returned as a topic

\footnotetext{
${ }^{29}$ The size of the impact of a variable on the odds of category X relative to category $\mathrm{Y}$ can be obtained by dividing the odds of category $\mathrm{X}$ relative to the base category by the of category $\mathrm{Y}$ relative to the base.

${ }^{30}$ These results are not reported in the present text but have been checked to be statistically significant.

${ }^{31}$ Age also has a positive impact on these odds but this does not necessarily mean that older entrepreneurs have better business survival chances.
} 
of interest in the field of economics, having played a central role in economic theory between the 18th and early 20th centuries (Hébert and Link, 1989, Van Praag, 1999). Moderate economic growth coupled with persistently high levels of unemployment stimulated expectations of entrepreneurship's potential as a source of job creation and economic growth (Acs, 1992; Thurik, 1996; Audretsch and Thurik, 2000; Carree and Thurik, 2003).

This ebb and flow of interest in entrepreneurship is probably due to variations of the role of entrepreneurship over time and across countries. Until the 1970s the proportion of self-employed and small businesses in most developed Western economies declined steadily. During this period, a focus on entrepreneurship was virtually absent from the European economic policy agenda. The exploitation of economies of scale and scope was thought to be at the heart of modern economies (Teece, 1993). Small businesses were considered to be a vanishing breed. This was also a period of relatively well-defined technological trajectories, of stable demand and of seemingly clear advantages of diversification. Neo-classical economics and equilibrium theory left little room for the concepts of initiative, autonomy and the struggle with new ideas and uncertainty. As a result, references to the entrepreneur receded from the microeconomic textbooks (Barreto, 1989; Kirchhoff, 1994). Audretsch and Thurik (2001 and 2004) characterize this period as one where stability, continuity and homogeneity were the cornerstones and label it the 'managed economy'. The last two decades witnessed massive downsizing and restructuring of many large firms built on certainty and the virtues of scale. This move away from large firms toward small, predominantly young firms was a sea-change, not just a temporary aberration. Audretsch and Thurik (2001 and 2004) label this new economic period, based less on the traditional inputs of natural resources, labor and capital, and more on the input of knowledge and ideas, as the 'entrepreneurial economy'. Paradoxically, the increased degree of uncertainty creates opportunities for small and young firms, and hence leads to higher rates of entrepreneurship. Further study shows that this change does not take place in all developed economies at the same time or to the same degree (Audretsch, Thurik, Verheul, Wennekers, 2002). Hence comparative research may explain these variations.

In spite of this growing interest in comparative research, the understanding of these variations in entrepreneurship at the macro level is limited. A comprehensive framework is needed to provide direction for this research. The goal of the present paper is to provide an overview and further direction for this emerging topic of macro-level analysis of entrepreneurship. To this end an Eclectic Framework is used explaining (developments in) entrepreneurship incorporating different streams of literature and spanning different disciplines. It is a framework for understanding and analyzing the determinants of entrepreneurship.

In its empirical part the present paper uses survey data (2002 and 2003) from the $15 \mathrm{EU}$ member states, Norway, Iceland, Liechtenstein and the US to establish the effect of demographic and other variables on various entrepreneurial engagement levels, such as "thinking about it", "taking steps for starting up”, "having a young business", "having an older business", etc. A multinomial logit model is used for estimating the influence of the explanatory variables on the various engagement levels. The five channel approach of the Eclectic Framework is used to classify the explanatory variables. Four of the five channels of the Eclectic Framework are "covered". Demographic variables such as gender, age and education level represent the supply channel, administrative complexities, availability of financial support and the respondents' self declared preference to be self-employed the preferences channel ${ }^{32}$, a rough measure of risk tolerance the risk reward profile channel, and residual country specific effects (covered by dummy variables) the demand channel.

\footnotetext{
${ }^{32}$ Administrative complexities and availability of capital are interpreted as part of the preference channel and not of the resources and abilities channel because these variables are measured at the perception level and no "real" indicator is identified. Alternatively, to the extent that these variables proxy the "real" situation, administrative complexities may be viewed as belonging to type 5 or even type 1 policy channels while availability of capital could be seen as having a relation with type 3 policy channel.
} 
The most important findings are that

- Relative to "not thinking about it" the odds of any other option are higher for men than for women while this effect is stronger for "having an active business" than for any other category.

- Perception of administrative complexities has no effect on the odds of "gave up", "thinking about it" and "taking steps" relative to "never thought about it".

- Perception of administrative complexities plays a negative role for higher levels of "engagement" ("having an active business").

- Perception of lack of financial support has no discriminative effect across the categories.

- European countries have lower odds than the US for levels of engagement up to "having a young business".

- European countries have higher odds than the US for the category "having an older business".

Future research should concentrate on

- The explanation of the country differences: to what extent are cultural aspects, sector composition of economic activity, market legislation, tax environment, bankruptcy law, job security, social security regimes, etc determining factors. ${ }^{33}$

- The role of the level and speed of economic development: to what extent do they have a moderating or mediating influence on the variables used in the present study and to what extent is this influence engagement level dependent. ${ }^{34}$

- The role of the wage level relative to self-employment income: this important variable is not available in the present data set while it is generally assumed to be important in shaping entrepreneurial activity. ${ }^{35}$

- The role of country specific aspiration levels: this role model effect could be captured, for instance, by engagement level averages.

${ }^{33}$ See Wennekers, Uhlaner and Thurik (2002) for some insights on the role of heterogeneity on the country level when explaining entrepreneurial activity.

${ }^{34}$ See Wennekers, van Stel, Thurik and Reynolds (2005) for an investigation of the influence of the level of economic development on nascent entrepreneurship across countries.

${ }^{35}$ See Parker (2004) for a literature review. 


\section{References}

Acs, Z.J., P. Arenius, M. Hay and M. Minniti, 2005, Global Entrepreneurship Monitor: 2004 Executive Report, Babson Park, MA: Babson College and London: London Business School

Acs, Z.J., 1992, Small business economics; a global perspective, Challenge 35, November/December, 38-44.

Acs, Z.J., D.B. Audretsch, P. Braunerhjelm and B. Carlsson, 2005, The missing link: the knowledge filter and entrepreneurship in endogenous growth, Papers on Entrepreneurship, Growth and Public Policy no 08-2004, Max Planck Institute of Economics, Jena, Germany.

Acs, Z.J., D.B. Audretsch and D.S. Evans, 1994, The determinants of variations in self-employment rates across countries and over time, Discussion Paper 871, Centre for Economic Policy Research, London.

Acs, Z.J., B. Carlsson, and C. Karlsson, 1999, Entrepreneurship, Small and Medium-Sized Enterprises and the Macroeconomy, Cambridge: Cambridge University Press.

Arenius, P. and M. Minniti, 2005, Perceptual variables and nascent entrepreneurship, Small Business Economics 24(3), 233-247.

Audretsch, D.B., M.A. Carree, A.J. van Stel and A.R. Thurik, 2002, Impeded industrial restructuring: the Growth Penalty, Kyklos 55(1).81-97.

Audretsch, D.B. and A.R. Thurik, 2000, Capitalism and democracy in the 21st century: from the managed to the entrepreneurial economy, Journal of Evolutionary Economics 10(1), 17-34.

Audretsch, D.B. and A.R. Thurik, 2001, What is new about the new economy: sources of growth in the managed and entrepreneurial economies, Industrial and Corporate Change 10(1), 25-48.

Audretsch, D.B. and A.R. Thurik, 2004, The model of the entrepreneurial economy, International Journal of Entrepreneurship Education 2(2), 143-166.

Audretsch, D.B., A.R. Thurik, I. Verheul and S. Wennekers, 2002, Entrepreneurship: Determinants and Policy in a European-US Comparison, Dordrecht: Kluwer Academic Publishers.

Barreto, H., 1989, The Entrepreneur in Economic Theory; Disappearance and Explanation, London: Routledge.

Bates, T., 1990, Entrepreneur human capital inputs and small business longevity, The Review of Economics and Statistics 72(4), 551-559.

Baumol, W.J., 1990, Entrepreneurship: productive, unproductive and destructive, Journal of Political Economy 98(5), 893-921.

Blanchflower, D.G., 2000, Self-employment in OECD countries, Labour Economics 7(5), 471-505.

Blanchflower, D.G., 2004, Self-employment: more may not be better, Swedish Economic Policy Review 11(2), forthcoming.

Blanchflower, D.G. and B.D. Meyer, 1994, A longitudinal analysis of the young self-employed in Australia and the United States, Small Business Economics 6(1), 1-19.

Blanchflower, D.G. and A. Oswald, 1998, What makes an entrepreneur? Journal of Labor Economics 16, $29-60$.

Blanchflower, D.G., A. Oswald and A. Stutzer, 2001, Latent entrepreneurship across nations, European Economic Review 45(4-6), 680-691.

Blau, D., 1987, A time-series analysis of self-employment in the United States, Journal of Political Economy 95(3), 445-467.

Brock, W.A. and D.S. Evans, 1989, Small business economics, Small Business Economics 1(1), 7-20.

Bull, I. and G.E. Willard, 1993, Towards a theory of entrepreneurship, Journal of Business Venturing 8, 183-195.

Burke, A.E., FitzRoy, F.R. and M.A. Nolan, 2000, When less is more: distinguishing between entrepreneurial choice and performance, Oxford Bulletin of Economics and Statistics 62(5), 565-587.

Busenitz, L.W., Gomez, C. and J.W. Spencer, 2000, Country institutional profiles: unlocking entrepreneurial phenomena, Academy of Management Journal 43(5) 994-1003.

Carree, M.A., A.J. van Stel, A.R. Thurik and A.R.M. Wennekers, 2002, Economic development and business ownership: an analysis using data of 23 OECD countries in the period 1976-1996, Small Business Economics 19(3), 271290.

Carree, M.A. and A.R. Thurik, 2003, The impact of entrepreneurship on economic growth, in D.B. Audretsch and Z.J. Acs (eds.) Handbook of Entrepreneurship Research, Boston/Dordrecht: Kluwer Academic Publishers, 437-471.

Carree, M.A. and A.R. Thurik (eds), 2006, The Handbook of Entrepreneurship and Economic Growth, International Library of Entrepreneurship, Cheltenham, UK and Brookfield, US: Edward Elgar Publishing Limited, forthcoming.

Casson, M.C., 1982, The Entrepreneur: an Economic Theory, Oxford: Martin Robertson.

Cooper, A.C. and W.C. Dunkelberg, 1987, Entrepreneurial research: old questions, new answers and methodological issues, American Journal of Small Business 11, 11-23.

Cooper, A.C., F.J. Gimeno-Gascon and C.Y. Woo, 1994, Initial human and financial capital as predictors of new venture performance, Journal of Business Venturing 9(5), 371-395.

Cressy, R., 1999, The Evans and Jovanovic equivalence theorem and credit rationing: another look, Small Business Economics 12(4), 295-297.

Cressy, R., 2000, Credit rationing or entrepreneurial risk aversion? an alternative explanation for the Evans and Jovanovic finding, Economics Letters 66(2), 235-240. 
Davidsson, P., 2004, Researching Entrepreneurship, International Studies in Entrepreneurship, Boston etc: Springer Science Inc.

Davidsson, P. and B. Honig (2003), The role of social and human capital among nascent entrepreneurs, Journal of Business Venturing 18 (3), 301-331.

Delmar, F. and P. Davidsson, 2000, Where do they come from? prevalence and characteristics of nascent entrepreneurs, Entrepreneurship and Regional Development 12, 1-23.

Douglas, E.J. and D.A. Shepherd, 2002, Self-employment as a career choice: attitudes, entrepreneurial intentions, and utility maximization, Entrepreneurship Theory and Practice 26(3), 81-90.

Earle, J.S. and Z. Sakova, 2000, Business start-ups or disguised unemployment? Evidence on the character of selfemployment from transition economies, Labor Economics 7(5), 575-601.

European Commission, 1999, Action Plan to Promote Entrepreneurship and Competitiveness, Directorate-General for Enterprise.

European Commission, 2004, Entrepreneurship Action Plan at http://europa.eu.int/comm/enterprise/entrepreneurship/action_plan.htm

Evans, D.S. and B. Jovanovic, 1989, An estimated model of entrepreneurial choice under liquidity constraints, Journal of Political Economy 97(4), 808-827.

Evans, D.S. and L.S. Leighton, 1989, Some empirical aspects of entrepreneurship, American Economic Review 79(3), 519-535.

Evans, D.S. and L.S. Leighton, 1990, Small business formation by unemployed and employed workers, Small Business Economics 2, 319-330.

EZ, 1999, The Entrepreneurial Society. Entrepreneurship: More Opportunities, Less Threats, Den Haag: Ministry of Economic Affairs.

Gavron, R., M. Cowling, G. Holtham and A. Westall, 1998, The Entrepreneurial Society, London: Institute for Public Policy Research.

Gelderen, M. van, A.R. Thurik and N. Bosma, 2005, Success and risk factors in the pre-startup phase, Small Business Economics 24(4), forthcoming.

Grilo, I. and J.M. Irigoyen, 2005, Entrepreneurship in the EU: to wish and not to be, Papers on Entrepreneurship, Growth and Public Policy no 01-2005, Max Planck Institute of Economics, Jena, Germany.

Grilo, I. and A.R. Thurik, 2004, Entrepreneurship in Europe, Papers on Entrepreneurship, Growth and Public Policy no 30-2004, Max Planck Institute of Economics, Jena, Germany.

Grilo, I. and A.R. Thurik, 2005a, Latent and actual entrepreneurship in Europe and the US: some recent developments, Papers on Entrepreneurship, International Entrepreneurship and Management Journal 1(4), forthcoming.

Grilo, I. and A.R. Thurik, 2005b, Entrepreneurship in the old and the new Europe, Papers on Entrepreneurship, Growth and Public Policy no ??-2005, forthcoming, Planck Institute of Economics, Jena, Germany.

Harada, N. and K. Kijima, 2005, Consumption-leisure preference structure: a new explanation of the Evans-Jovanovic results for entrepreneurial choice, Small Business Economics 24(2), 187-191.

Hébert, R.F. and A.N. Link, 1989, In search of the meaning of entrepreneurship, Small Business Economics 1(1), 3949.

Holtz-Eakin, D., D. Joulfaian and H.S. Rosen, 1994, Entrepreneurial decisions and liquidity constraints, Rand Journal of Economics 25(2), 334-347.

Hurst, E. and A. Lusardi, 2004, Liquidity constraints, household wealth and entrepreneurship, Journal of Political Economy 112(2), 319-347.

Jovanovic, B., 1982, Selection and the evolution of industry, Econometrica 50, 649-670.

Jovanovic, B., 1994, Firm formation with heterogeneous management and labour skills, Small Business Economics 6, 185-191.

Kirchhoff, B.A., 1994, Entrepreneurship and Dynamic Capitalism, Westport, CT: Praeger.

Lin, Z., G. Picot and J. Compton, 2000, The entry and exit dynamics of self-employment in Canada, Small Business Economics 15, 105-125.

Lucas, R., 1978, On the size distribution of business firms, Bell Journal of Economics 9(3), 508-523.

Lumpkin, G.T. and G.G. Dess, 1996, Clarifying the entrepreneurial orientation construct and linking it to performance, Academy of Management Review 21(1), 135-172.

Knight, F.H., 1921, Risk, Uncertainty and Profit, New York: Houghton Mifflin.

Kuznetz, S., 1966, Modern Economic Growth: Rate, Structure and Spread, New Haven: Yale University Press.

Minniti, M., P. Arenius and N. Langowitz, 2005, GEM 2004 Report on Women and Entrepreneurship, Centre for Women's Leadership at Babson College / London Business School.

Noorderhaven, N.G., A.R.M. Wennekers, A.R. Thurik and A. van Stel, 2004, Self-employment across 15 European countries: the role of dissatisfaction, Entrepreneurship: Theory and Practice 29(1), 447-466. 
OECD, 1998, Fostering Entrepreneurship, the OECD Jobs Strategy, Paris: OECD.

Parker, S.C., 2004, The Economics of Self-Employment and Entrepreneurship, Cambridge: Cambridge University Press.

Praag, M.C. van, 1999, Some classic views on entrepreneurship, De Economist 147(3), 311-335.

Praag, M.C. van and H. van Ophem, 1995, Determinants of willingness and opportunity to start as an entrepreneur, Kyklos 48(4), 513-540.

Rees, H. and A. Shah, 1986, An empirical analysis of self- employment in the UK, Journal of Applied Econometrics 1(1), 95-108.

Reynolds, P.D., 1997, Who starts new firms? - Preliminary explorations of firms-in-gestation, Small Business Economics 9(5), 449-462.

Reynolds, P.D., N. Bosma, E. Autio, S. Hunt, N. de Bono, I. Servais, P. Lopez-Garcia and N. Chin, 2005, Global entrepreneurship monitor: data collection design and implementation 1998-2003, Small Business Economics 24(3), 205-231.

Reynolds, P.D., Bygrave, W.D., Autio, E., Cox, L.W. and M. Hay, 2002, Global Entrepreneurship Monitor, 2002 Executive Report, Babson College, London Business School and Kauffman Foundation.

Reynolds, P.D., M. Hay and S.M. Camp, 1999, Global Entrepreneurship Monitor: 1999 Executive Report, Babson College, London Business School and the Kauffman Center for Entrepreneurial Leadership.

Reynolds, P.D. and S.B. White, 1997, The Entrepreneurial Process: Economic Growth, Men, Women and Minorities, Westport, CT and London: Quorum Books.

Robinson, P.B. and E.A. Sexton, 1994, The effect of education and experience on self-employment success, Journal of Business Venturing 9(2), 141-156.

Stel, A. van, 2005, COMPENDIA: Harmonizing business ownership data across countries and over time, International Entrepreneurship and Management Journal 1(1), 105-123.

Stevenson, L. and A. Lundström, 2001, Patterns and trends in entrepreneurship/SME policy and practice in ten economies, Entrepreneurship Policy for the Future Series, Vol. 3, Swedish Foundation for Small Business Research.

Storey, D.J., 1994, Understanding the Small Business Sector, London/New York: Routledge.

Taylor, M.P., 2001, Self-employment and windfall gains in Britain: evidence from panel data, Economica 68(272), 539-565.

Teece, D.J., 1993, The dynamics of industrial capitalism: perspectives on Alfred Chandler's scale and scope, Journal of Economic Literature 31,199-225.

Thurik, A.R., 1996, Small firms, entrepreneurship and economic growth, in: P.H. Admiraal (ed.), Small Business in the Modern Economy, Oxford: Basil Blackwell Publishers, 126-152.

Thurik, A.R., 1999, Entrepreneurship, industrial transformation and growth, in: G.D. Libecap (ed.), The Sources of Entrepreneurial Activity: Vol. 11, Advances in the Study of Entrepreneurship, Innovation, and Economic Growth, Stamford, CT: JAI Press, 29-65.

Uhlaner, L. and A.R. Thurik, 2004, Post-materialism: a cultural factor influencing total entrepreneurial activity across nations, Papers on Entrepreneurship, Growth and Public Policy no 07-2004, Max Planck Institute of Economics, Jena, Germany.

Verheul, I., S. Wennekers, D. Audretsch and R. Thurik, 2002, An eclectic theory of entrepreneurship: policies, institutions and culture, In: D.B. Audretsch, A.R. Thurik, I. Verheul and A.R.M. Wennekers (eds), Entrepreneurship: Determinants and Policy in a European-US Comparison, Boston/Dordrecht: Kluwer Academic Publishers, 11-81.

Vivarelli, M., 2004, Are all the potential entrepreneurs so good? Small Business Economics 23(1), 41-49.

Wagner, J., 2003, Testing Lazear's Jack-of-all-trades view of entrepreneurship with German micro data, Applied Economics Letters 10(11), 687-689.

Wagner, J., 2004, Nascent entrepreneurs, IZA Discussion paper 1293, Institute for the Study of Labor, Bonn, Germany.

Wennekers, S., A. van Stel, R. Thurik and P. Reynolds, 2005, Nascent entrepreneurship and the level of economic development, Small Business Economics 24(3), 293-309.

Wennekers, A.R.M. and A.R. Thurik, 1999, Linking entrepreneurship and economic growth, Small Business Economics 13(1), 27-55.

Wennekers, S., R. Thurik, A. van Stel and N. Noorderhaven, 2003, Uncertainty avoidance and the rate of business ownership across 22 OECD countries, 1976-2000, Tinbergen Institute Discussion Paper TI03-089/3, Erasmus University Rotterdam, NL.

Wennekers, A.R.M., L. Uhlaner, and A.R. Thurik, 2002, Entrepreneurship and its conditions: a macro perspective, International Journal of Entrepreneurship Education 1(1), 25-64.

Wit, G. de and F.A.A.M. van Winden, 1989, An empirical analysis of self-employment in the Netherlands, Small Business Economics 1(4), 263-284.

Xu, B., 1998, A Reestimation of the Evans-Jovanovic entrepreneurial choice model, Economics Letters 58(1), 91-95. 
Table 1: Percentages per engagement level per country

\begin{tabular}{|c|c|c|c|c|c|c|c|c|}
\hline & Never considered & Gave up & Thinking & Taking steps & Business $<$ 3yrs & Business $>3$ yrs & No longer & Observations \\
\hline Belgium & 68 & 9 & 8 & 2 & 2 & 5 & 6 & 853 \\
\hline Denmark & 44 & 13 & 18 & 3 & 3 & 9 & 10 & 819 \\
\hline Germany & 50 & 13 & 16 & 3 & 4 & 7 & 7 & 1297 \\
\hline Greece & 46 & 11 & 17 & 2 & 4 & 8 & 12 & 875 \\
\hline Spain & 60 & 8 & 15 & 2 & 2 & 6 & 7 & 1129 \\
\hline France & 61 & 14 & 11 & 1 & 1 & 4 & 7 & 1337 \\
\hline Ireland & 52 & 7 & 21 & 5 & 4 & 7 & 5 & 856 \\
\hline Italy & 62 & 7 & 9 & 3 & 2 & 7 & 10 & 1362 \\
\hline Luxembourg & 60 & 16 & 8 & 2 & 2 & 6 & 6 & 814 \\
\hline Netherlands & 56 & 11 & 10 & 1 & 3 & 9 & 9 & 847 \\
\hline Austria & 54 & 8 & 20 & 2 & 4 & 7 & 5 & 808 \\
\hline Portugal & 61 & 9 & 11 & 3 & 3 & 6 & 7 & 815 \\
\hline Finland & 54 & 12 & 11 & 2 & 3 & 10 & 9 & 839 \\
\hline Sweden & 66 & 5 & 9 & 3 & 4 & 7 & 6 & 712 \\
\hline UK & 53 & 8 & 15 & 2 & 5 & 7 & 10 & 1149 \\
\hline Iceland & 44 & 5 & 12 & 3 & 6 & 18 & 13 & 536 \\
\hline Norway & 50 & 12 & 7 & 2 & 5 & 12 & 11 & 733 \\
\hline Liechtenstein & 48 & 13 & 12 & 4 & 5 & 12 & 5 & 790 \\
\hline US & 49 & 3 & 23 & 8 & 7 & 5 & 5 & 1050 \\
\hline
\end{tabular}

Source: Flash Eurobarometer Surveys 134 and 146 (conducted in 2002 and 2003). 
Table 2: Odds relative to "never having considered starting a business": effect of one unit change in independent variables

\begin{tabular}{|c|c|c|c|c|c|c|c|c|c|c|c|c|}
\hline & \multicolumn{2}{|c|}{ Gave up } & \multicolumn{2}{|c|}{ Thinking } & \multicolumn{2}{|c|}{ Taking steps } & \multicolumn{2}{|c|}{ Business $<$ 3yrs } & \multicolumn{2}{|c|}{ Business $>3 y r s$} & \multicolumn{2}{|c|}{ No longer } \\
\hline & Odds & P-value & Odds & P-value & Odds & P-value & Odds & P-value & Odds & P-value & Odds & P-value \\
\hline Men & 1,506 & 0,000 & 1,538 & 0,000 & 2,124 & 0,000 & 1,934 & 0,000 & 2,515 & 0,000 & 1,693 & 0,000 \\
\hline Age & 0,998 & 0,128 & 0,959 & 0,000 & 0,959 & 0,000 & 0,986 & 0,000 & 1,017 & 0,000 & 1,040 & 0,000 \\
\hline Low education & 0,823 & 0,042 & 0,795 & 0,032 & 0,830 & 0,397 & 0,580 & 0,005 & 0,666 & 0,000 & 0,969 & 0,725 \\
\hline High education & 1,332 & 0,000 & 1,484 & 0,000 & 2,265 & 0,000 & 1,605 & 0,000 & 1,422 & 0,000 & 1,001 & 0,992 \\
\hline Preferences & 2,412 & 0,000 & 4,747 & 0,000 & 9,363 & 0,000 & 8,363 & 0,000 & 9,261 & 0,000 & 2,650 & 0,000 \\
\hline Lack finance & 1,028 & 0,686 & 0,958 & 0,487 & 0,833 & 0,115 & 0,870 & 0,170 & 0,874 & 0,073 & 0,936 & 0,379 \\
\hline Complexities & 1,002 & 0,971 & 0,891 & 0,048 & 0,841 & 0,110 & 0,700 & 0,000 & 0,736 & 0,000 & 0,786 & 0,001 \\
\hline Risk tolerance & 1,195 & 0,001 & 1,319 & 0,000 & 1,137 & 0,220 & 1,437 & 0,000 & 1,278 & 0,000 & 1,174 & 0,010 \\
\hline Belgium & 2,717 & 0,000 & 0,437 & 0,000 & 0,300 & 0,000 & 0,440 & 0,003 & 1,515 & 0,069 & 1,154 & 0,503 \\
\hline Denmark & 6,029 & 0,000 & 1,436 & 0,007 & 0,709 & 0,182 & 0,981 & 0,939 & 4,176 & 0,000 & 3,124 & 0,000 \\
\hline Germany & 5,418 & 0,000 & 1,053 & 0,672 & 0,617 & 0,025 & 0,897 & 0,592 & 2,771 & 0,000 & 1,904 & 0,001 \\
\hline Greece & 4,546 & 0,000 & 1,096 & 0,517 & 0,433 & 0,003 & 1,108 & 0,646 & 3,193 & 0,000 & 3,251 & 0,000 \\
\hline Spain & 2,158 & 0,000 & 0,530 & 0,000 & 0,210 & 0,000 & 0,302 & 0,000 & 1,331 & 0,169 & 1,405 & 0,086 \\
\hline France & 4,275 & 0,000 & 0,492 & 0,000 & 0,230 & 0,000 & 0,275 & 0,000 & 1,144 & 0,527 & 1,466 & 0,043 \\
\hline Ireland & 2,300 & 0,000 & 0,965 & 0,790 & 0,705 & 0,106 & 0,678 & 0,085 & 1,802 & 0,005 & 1,019 & 0,934 \\
\hline Italy & 1,886 & 0,003 & 0,358 & 0,000 & 0,344 & 0,000 & 0,388 & 0,000 & 1,706 & 0,006 & 1,882 & 0,001 \\
\hline Luxembourg & 5,260 & 0,000 & 0,429 & 0,000 & 0,296 & 0,000 & 0,330 & 0,000 & 1,621 & 0,032 & 1,320 & 0,196 \\
\hline Netherlands & 4,323 & 0,000 & 0,601 & 0,001 & 0,279 & 0,000 & 0,757 & 0,236 & 3,328 & 0,000 & 2,528 & 0,000 \\
\hline Austria & 3,271 & 0,000 & 1,574 & 0,001 & 0,553 & 0,041 & 1,344 & 0,182 & 3,173 & 0,000 & 1,314 & 0,238 \\
\hline Portugal & 2,523 & 0,000 & 0,375 & 0,000 & 0,300 & 0,000 & 0,496 & 0,004 & 1,348 & 0,177 & 1,041 & 0,853 \\
\hline Finland & 5,017 & 0,000 & 0,783 & 0,106 & 0,432 & 0,005 & 0,741 & 0,257 & 4,773 & 0,000 & 2,557 & 0,000 \\
\hline Sweden & 1,567 & 0,071 & 0,499 & 0,000 & 0,529 & 0,016 & 0,711 & 0,169 & 1,796 & 0,009 & 1,083 & 0,726 \\
\hline UK & 2,792 & 0,000 & 0,870 & 0,282 & 0,478 & 0,002 & 0,964 & 0,853 & 1,954 & 0,001 & 2,182 & 0,000 \\
\hline Iceland & 1,758 & 0,043 & 0,581 & 0,002 & 0,356 & 0,001 & 0,990 & 0,967 & 4,873 & 0,000 & 3,404 & 0,000 \\
\hline Norway & 4,797 & 0,000 & 0,490 & 0,000 & 0,469 & 0,008 & 1,295 & 0,256 & 4,911 & 0,000 & 3,514 & 0,000 \\
\hline Liechtenstein & 4,837 & 0,000 & 0,610 & 0,001 & 0,508 & 0,005 & 0,877 & 0,547 & 3,680 & 0,000 & 1,613 & 0,033 \\
\hline
\end{tabular}

Note: DK/NA observations have been dropped from the sample. Base category: "It never came to your mind".

Source: Flash Eurobarometer Surveys 134 and 146 (conducted in 2002 and 2003). 
Figure 1: Eclectic Framework and the variables used in the present study

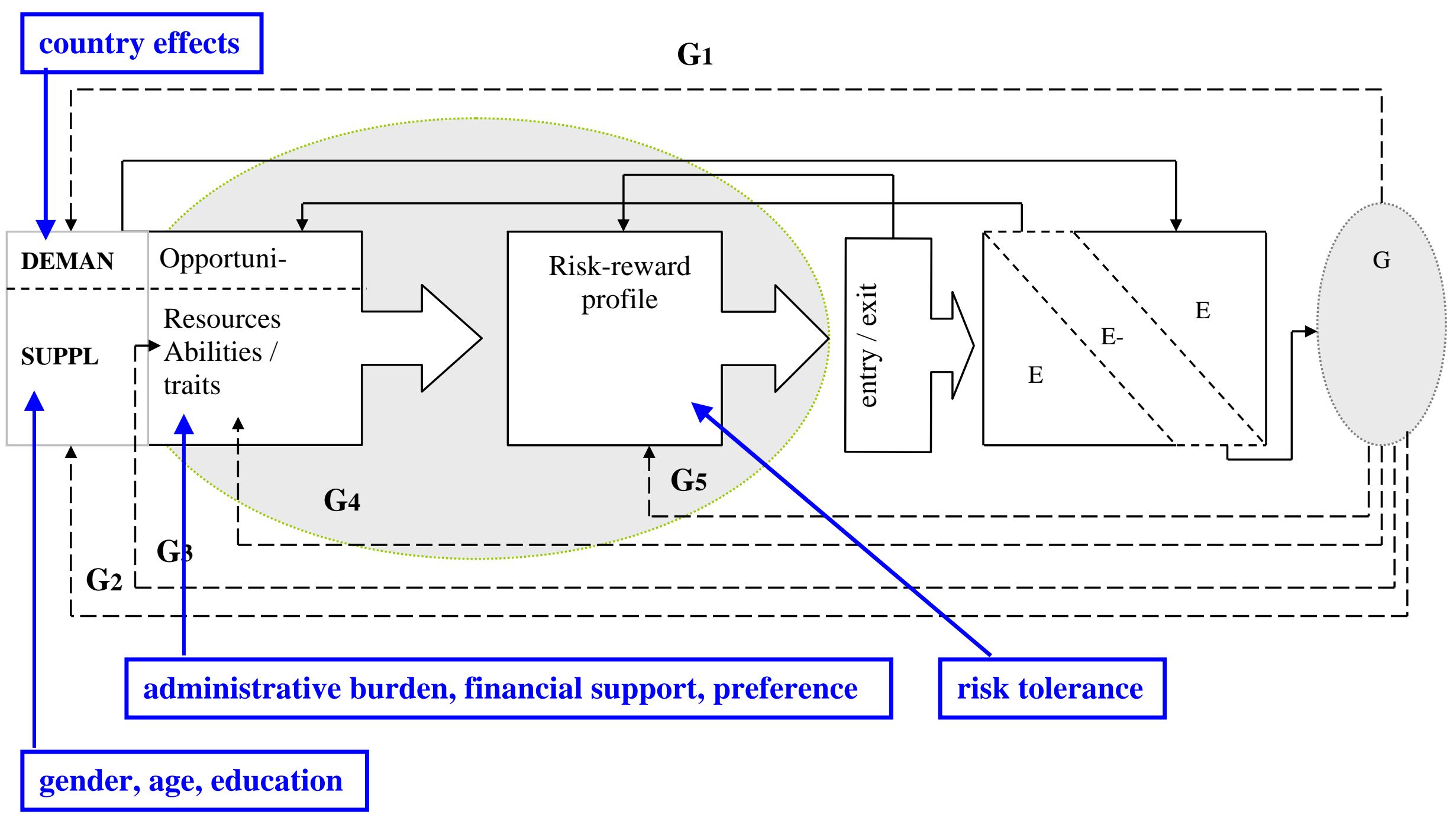

